\title{
Soil erosion and organic carbon export by wet snow avalanches
}

\author{
O. Korup ${ }^{1}$ and C. Rixen ${ }^{2}$ \\ ${ }^{1}$ Institute of Earth and Environmental Sciences, University of Potsdam, 14476 Potsdam, Germany \\ ${ }^{2}$ WSL Institute for Snow and Avalanche Research SLF, 7260 Davos, Switzerland \\ Correspondence to: O. Korup (oliver.korup@geo.uni-potsdam.de)
}

Received: 26 November 2013 - Published in The Cryosphere Discuss.: 2 January 2014

Revised: 9 March 2014 - Accepted: 13 March 2014 - Published: 14 April 2014

\begin{abstract}
Many mountain belts sustain prolonged snow cover for parts of the year, although enquiries into rates of erosion in these landscapes have focused almost exclusively on the snow-free periods. This raises the question of whether annual snow cover contributes significantly to modulating rates of erosion in high-relief terrain. In this context, the sudden release of snow avalanches is a frequent and potentially relevant process, judging from the physical damage to subalpine forest ecosystems, and the amount of debris contained in avalanche deposits. To quantitatively constrain this visual impression and to expand the sparse literature, we sampled sediment concentrations of $n=28$ riverspanning snow-avalanche deposits (snow bridges) in the area around Davos, eastern Swiss Alps, and inferred an ordersof-magnitude variability in specific fine sediment and organic carbon yields $\left(1.8\right.$ to $830 \mathrm{t} \mathrm{km}^{-2} \mathrm{yr}^{-1}$, and 0.04 to $131 \mathrm{t} \mathrm{C} \mathrm{km}^{-2} \mathrm{yr}^{-1}$, respectively). A Monte Carlo simulation demonstrates that, with a minimum of free parameters, such variability is inherent to the geometric scaling used for computing specific yields. Moreover, the widely applied method of linearly extrapolating plot scale sample data may be prone to substantial under- or overestimates. A comparison of our inferred yields with previously published work demonstrates the relevance of wet snow avalanches as prominent agents of soil erosion and transporters of biogeochemical constituents to mountain rivers. Given that a number of snow bridges persisted below the insulating debris cover well into the summer months, snow-avalanche deposits also contribute to regulating in-channel sediment and organic debris storage on seasonal timescales. Finally, our results underline the potential shortcomings of neglecting erosional processes in the winter and spring months in mountainous terrain subjected to prominent snow cover.
\end{abstract}

\section{Introduction}

Snow cover is a key visual and hydrological characteristic of many mountain belts during the winter months. Nevertheless, the plethora of studies dedicated to quantifying rates of erosion and sediment transport in steeplands has largely neglected the role of snow cover in potentially modulating these rates (Stanchi et al., 2014). Snow avalanching in particular is an important and seasonally recurring process in many high-altitude and high-latitude regions. Most research on snow avalanches has focused on mechanisms of their formation, runout, and consequent hazards to lives, buildings, and infrastructure (e.g. Schweizer et al., 2003; Sovilla et al., 2006). The role of snow avalanches as transporters of sediment and biogeochemical constituents has been acknowledged and attested to (e.g. Luckman, 1977, 1978; Gardner, 1983; Ward, 1985; Nyberg, 1989; Decaulne and Saemundsson, 2006), but received comparatively scarce attention from a quantitative view. Hence, compared to other processes of hillslope mass wasting such as rockfalls or debris flows, little is known about the geomorphic and ecological impacts of snow avalanches (Fig. 1). Yet this knowledge is vital to understanding comprehensive mass budgets in subalpine, alpine, and circumpolar regions, where snow cover is dominant for a significant fraction of the hydrological year. Neglecting the erosion, transport, and deposition potential by snow avalanches may thus underestimate rates of sediment and nutrient cycling in areas with steep slopes and high topographic relief.

A number of studies indicate that snow avalanches may mobilize rockfall debris and significant amounts of large woody debris (LWD), ultimately creating distinct landforms such as avalanche cones, protalus ramparts, impact ponds or plunge pools (Huber, 1982; André, 1990; Luckman et al., 

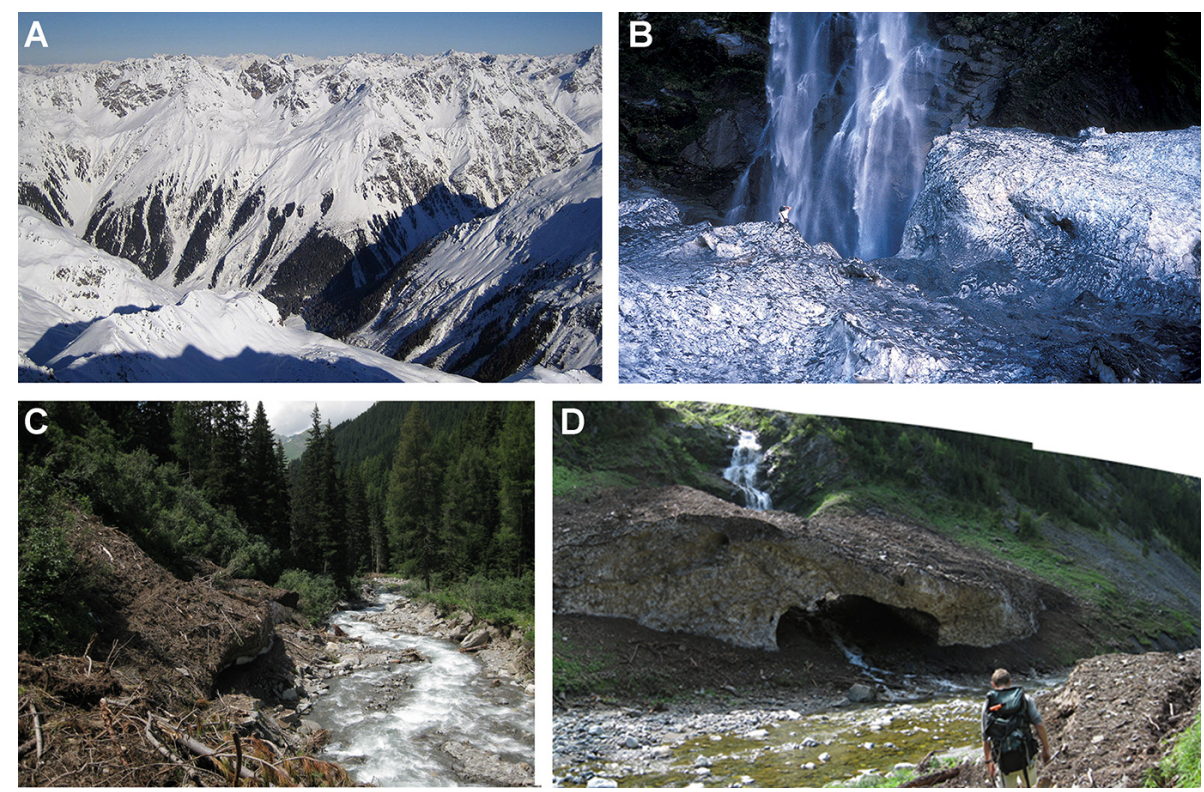

Fig. 1. Relevance of snow cover and avalanche erosion in mountainous terrain: (A) large avalanche chutes in the eastern Swiss Alps. (B) Sediment-rich avalanche debris below steep bedrock sluice, Matukituki Valley, Southern Alps, New Zealand; note person for scale. (C) Eroded snow-avalanche bridge with thick cover of organic debris, Flüelabach, eastern Swiss Alps (this study). (D) Remnants of snowavalanche bridge, Zügenschlucht, eastern Swiss Alps (this study).

1994; Blikra and Selvik, 1998; Jomelli, 1999; de Scally et al., 2001). Snow avalanches are an important nourishing agent for large valley glaciers and rock glaciers (Humlum et al., 2007), but may also modulate ecological diversity in subalpine areas (Butler, 2001). Disturbance through avalanches has been shown to increase plant and animal diversity at the hillslope scale (Rixen et al., 2007; Bebi et al., 2009; Kulakowski et al., 2011). From the bulk of empirical studies, only a few have attempted to quantify erosion and sediment transport by snow avalanches (Ackroyd, 1987; Bell et al., 1990; Heckmann et al., 2002, 2005; Sass et al., 2010); even fewer have begun addressing the effect of snow avalanches on soil erosion and the concomitant cycling of biogeochemical constituents such as organic carbon or nitrogen (Freppaz et al., 2010; Ceaglio et al., 2012; Confortola et al., 2012).

Here we contribute to closing this knowledge gap. Guided by multiple visual field checks, we hypothesize that snow avalanches may transport significant amounts of sediment and particulate organic carbon. Our objective is to quantitatively estimate to the first order the mobilization and export of sediment and organic carbon by wet snow avalanches. Using field sampling, we focus on the fine fractions of sediment and organic carbon entrained in those avalanches that formed snow bridges in the area around Davos, eastern Swiss Alps. Melt-out of these snow bridges delivers fine material to steep mountain-river channels, thus warranting instantaneous fluvial transport of sediment and particulate organic carbon (POC) away from the study sites. Ultimately, we point to the question of whether the end of the snow-cover season is a pe- riod of enhanced mobilization of sediment and biogeochemical constituents.

\section{Methods}

We sampled $n=28$ deposits of snow avalanches that occurred during the 2007/2008 winter and spring season in the headwaters of the Landquart and Landwasser rivers in the eastern Swiss Alps (Fig. 2). All of the deposits were $>100 \mathrm{~m}^{2}$ in surface area, had entered steep mountain-river channels, and formed ephemeral or partly collapsed snow bridges, locally exposing the full avalanche-snow profile. Clearly visible and local decimetre-thick patches of sediment and organic detritus had accumulated on the deposit surfaces, making them amenable targets for field sampling. Assuming that this sediment did not undergo any significant sorting during transport (Jomelli and Bertran, 2001), we took 100 point samples of debris-cover thickness per deposit using a ruler at an estimated accuracy to the nearest centimetre with an estimated sampling error of $\pm 20 \%$. Our measurements also included irregular bare snow surfaces. We selected these sample points blindfolded and at random while moving across the deposits as to exclude potential bias by spatial autocorrelation. Exposures of dissected or collapsed snow-bridge deposits revealed further thin ( $<\mathrm{cm}$-scale) and discontinuous bands of sediment within the snow column, but none displayed significant sediment content below the upper $10 \mathrm{~cm}$ and therefore the snow below was largely clean. 


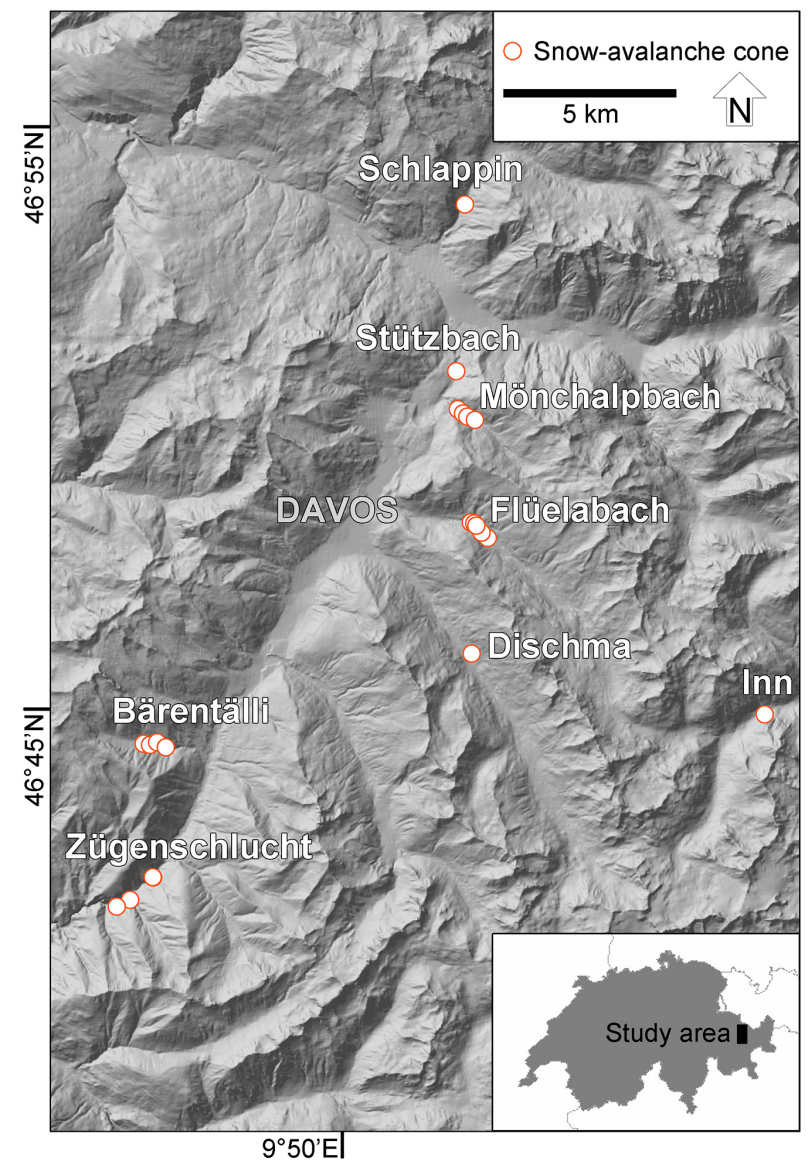

Fig. 2. Map of study area and locations of the $n=28$ sampled wet snow-avalanche deposits in the eastern Swiss Alps, canton of Grisons.

We also collected cover sediment and organic detritus from $1 \mathrm{~m}^{2}$ square-shaped plots that we selected randomly on the snow-avalanche deposits by throwing a marker onto the deposit while blindfolded. We avoided unrepresentative patches of snow that were either nearly devoid of sediment or covered with sediment $>10 \mathrm{~cm}$. Thus retrieved $n=28 \mathrm{sam}-$ ples comprised $>340 \mathrm{~kg}$ of surface material that was dried at room temperature and prepared for particle-size analysis and loss on ignition in the laboratory. For the particle-size analysis, we separately recorded any hand-picked LWD, or individual clasts exceeding gravel size (>63 mm). Samples were separated and sieved into the following size fractions: coarse organic material, coarse inorganic material, $>63 \mathrm{~mm}$, $>45 \mathrm{~mm},>32 \mathrm{~mm},>20 \mathrm{~mm},>10 \mathrm{~mm}$, and $<10 \mathrm{~mm}$. For the loss-on-ignition analysis, a representative subsample of $1 \mathrm{~kg}$ per sample was sieved to retrieve the fine fraction $(<2 \mathrm{~mm})$. Approximately $7 \mathrm{~g}$ of both fractions $(<2 \mathrm{~mm}$ and $2-10 \mathrm{~mm})$ were then heated at $550{ }^{\circ} \mathrm{C}$ for 2 hours to burn the organic material. The deposits were predominantly of crystalline origin; hence we did not differentiate between crystalline and carbonate deposits in order to potentially exclude the inorganic carbon fraction in the sediment.

In order to gauge the variability of specific sediment and organic carbon yields from snow avalanches, we conducted a Monte Carlo simulation that combined our field data with geometric scaling properties of snow avalanches. Assuming that snow-avalanche deposit area $A$ has an inverse powerlaw scaling of the form $p(A) \propto A^{-\alpha}$, where smaller events occur systematically more frequently than larger ones (e.g. Birkeland and Landry, 2002), we estimated the scaling exponent $\alpha$ from simple bootstrapping ( $n=10^{5}$ iterations) of our field-based measurements of $A$ to which we added a uniformly distributed estimation error of $\pm 20 \%$ for each iteration. We approximated the resulting density function of $\alpha$ with a normal distribution $N(\mu=1.7, \sigma=0.1)$, which we then used to subsequently draw random values of $\alpha_{i}$ to generate power-law distributed values $A_{i} \in\left[A_{\min }, A_{\mathrm{C}}\right]$, where $A_{\text {min }}$ is an arbitrarily set minimum avalanche-deposit area covered by debris $\left[\mathrm{m}^{2}\right]$, and $A_{\mathrm{C}}$ is the maximum contributing drainage-basin area $\left[\mathrm{m}^{2}\right]$, which we assumed as an approximate upper limit to the avalanche-deposit area in order to make our calculations objective and replicable. We then multiplied these simulated avalanche-deposit areas $A_{i}$ with debris-cover thickness per $0.01 \mathrm{~m}^{2}$ of deposit area that we randomly sampled from histograms of our field-derived data, using the individual bin counts as weights in the sampling process. We repeated this exercise using both site-specific and a pooled histogram of debris-cover depths, thus creating $n=1000$ simulated debris volumes per avalanche cone. We obtained specific yields [ $\mathrm{t} \mathrm{km}^{-2} \mathrm{yr}^{-1}$ ] by dividing these simulated volumes by $A_{\mathrm{C}}$, and multiplying by the fraction of organic debris obtained from the square plots, simplistically assuming a bulk debris density of $1.8 \mathrm{t} \mathrm{m}^{-3}$, and that the debris content surveyed in the field amounted to a full year's yield. Finally, we obtained the more traditional estimates of sediment and organic carbon yields by multiplying the average debris contents from the sample plots by the field-estimated deposit areas.

\section{Results}

We find that the mean thickness of surface sediment and organic detritus on the snow-avalanche deposits is highly variable, ranging from next to nil for patches of clear snow or surface ice to $>1 \mathrm{~m}$ in the case of boulder-sized rock fragments, tree logs, or thick nests of large woody debris (Fig. 1c). We recorded a maximum boulder size of $3.5 \mathrm{~m}$ at one location; at selected sites, we estimated the median of the largest handpicked clast diameters $D_{50}$ at 0.35 to $0.47 \mathrm{~m}$. Continuous debris thickness measured in the field is distinctly skewed with $90 \%$ of all data $<6 \mathrm{~cm}$ with an interquartile range of $2 \mathrm{~cm}$ (Fig. 3). We estimate the fraction of cover at 75-80\% per unit area on average. The sampled surface concentration of sediment varied from 1.1 to $42.7 \mathrm{~kg} \mathrm{~m}^{-2}$ (Fig. 3). 


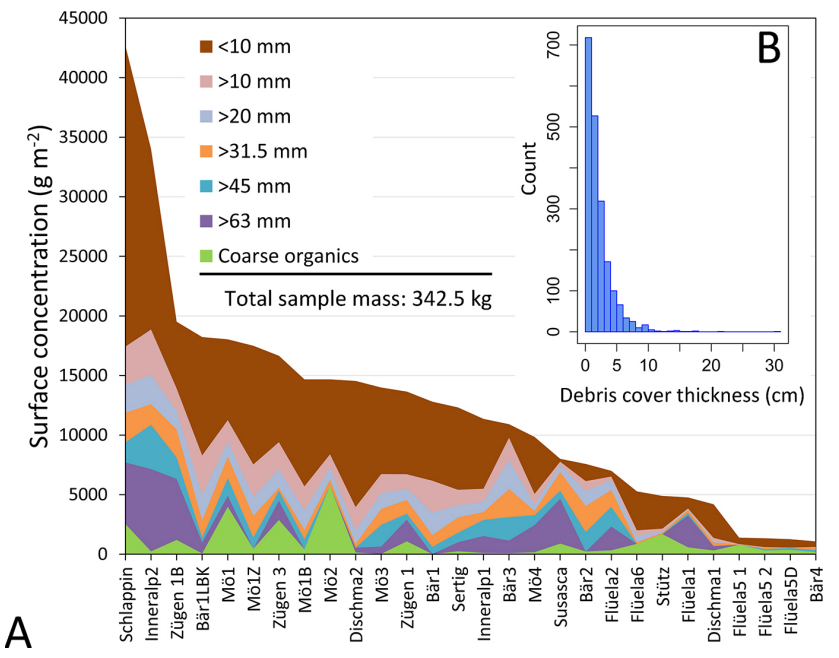

Fig. 3. Characteristics of debris cover on the surface of $n=28$ wet snow-avalanche deposits. (A) Grain-size characteristics and surface concentration of debris cover from $n=28$ snow-avalanche cones. Most organic content is contained in the size fraction $<2 \mathrm{~mm}$. (B) Histogram of debris-cover thickness measured blindfolded and randomly on all avalanche surfaces $(n=2800$ point measurements).

The median fraction of organic material in these surface deposits was nearly twice as high, i.e. $\sim 30 \%$, in the grainsize fractions $<2 \mathrm{~mm}$, compared to coarse $(>2 \mathrm{~mm})$ material ( $\sim 17 \%$; Fig. 3a). The median fraction of organic carbon in coarse leaf litter, small branches, etc. was $\sim 6 \%$. Overall, we measured surface concentrations of 0.02 to $5.7 \mathrm{~kg} \mathrm{C} \mathrm{m}^{-2}$.

Linear interpolation of these plot-derived concentrations results in specific sediment yields of 1.8 to $830 \mathrm{t} \mathrm{km}^{-2} \mathrm{yr}^{-1}$, depending on study site, for this particular season (red curve; Fig. 4). The corresponding estimates of specific yields of organic carbon amount to 0.04 to $131 \mathrm{tC} \mathrm{km}^{-2} \mathrm{yr}^{-1}$. The Monte Carlo simulation reveals that power-law distributed avalanche-deposit areas multiplied by abundance-weighted debris cover result in a variability of specific yields that spans over three and two orders of magnitude for sediment and organic carbon, respectively. By design, the range of these simulated estimates depends on the arbitrary minimum snowavalanche area $A_{\min }$ (Fig. 4). Using the pooled histogram of debris-cover thickness causes some slightly higher values, although the resulting distributions remain similar in shape.

The variation of these specific yields between individual sites is about two orders of magnitude with respect to the median values (Fig. 5). The majority of avalanche tracks have given rise to specific sediment yields of $10^{1}$ to $10^{2} \mathrm{t} \mathrm{km}^{-2} \mathrm{yr}^{-1}$, whereas the specific carbon yields range mostly from $10^{0}$ to $10^{1} \mathrm{t} \mathrm{km}^{-2} \mathrm{yr}^{-1}$, which is consistent with the distribution of the fraction of organic carbon in the individual samples.
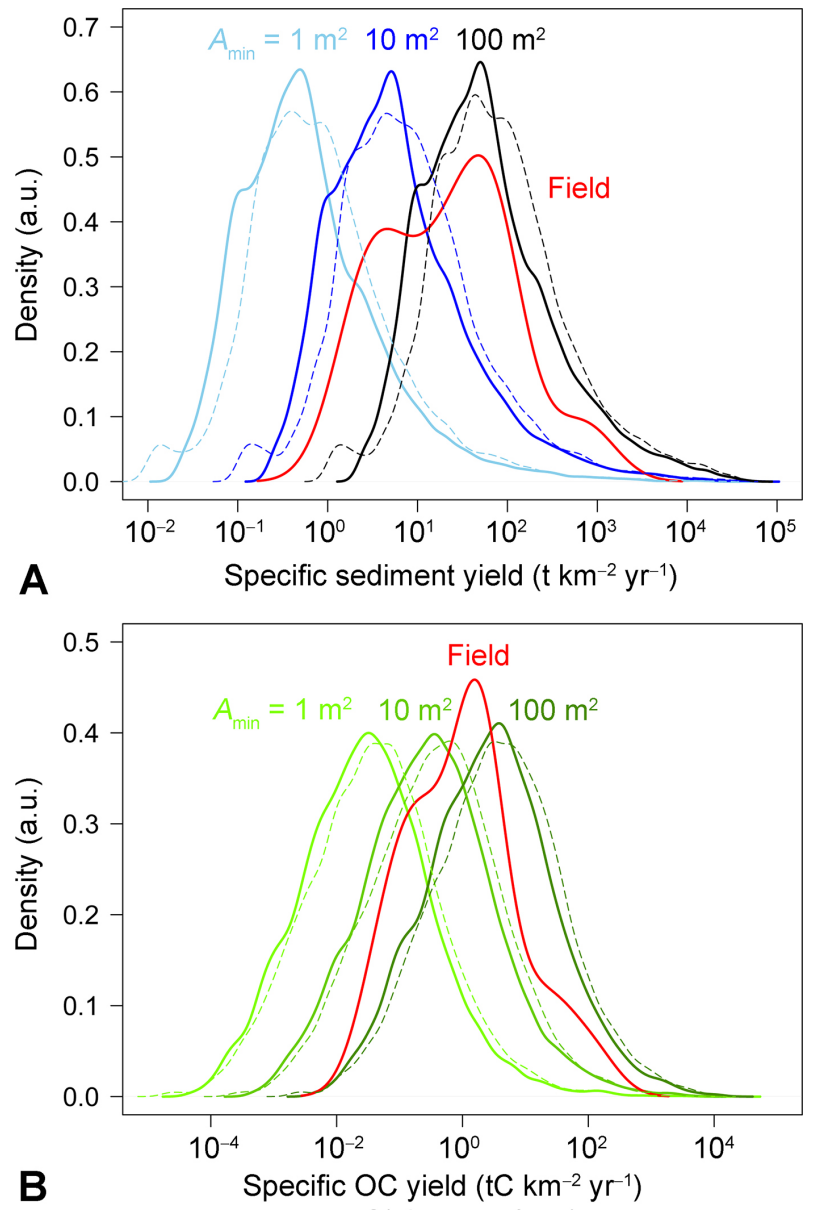

Fig. 4. Probability-density estimates of simulated and field-derived $\log _{10}$-transformed specific sediment and organic yields from wet snow avalanches in the area around Davos, eastern Swiss Alps. Simulations assumed power-law distributed avalanche-deposit areas with varying arbitrary minimum debris-covered areas $A_{\text {min }}$, and randomly sampled deposit thicknesses based on field measurements (each thick line represents one avalanche cone; dashed lines are pooled for all sites; see text for details). Thick red lines are estimates derived from linear interpolation of debris content measured from $1 \mathrm{~m}^{2}$ sample squares. More than $90 \%$ of the estimated sediment and carbon yields are spread over three and four orders of magnitude, respectively.

\section{Discussion}

We provide some of the first quantitative estimates of specific yields of avalanche-borne sediment and organic carbon from the eastern Swiss Alps. Before discussing these yields further, we emphasize that our results are first-order estimates and subject to a number of caveats. Most importantly, our yield estimates are based on a novel approach of statistically extrapolating randomly selected plot samples. While it has been practice in previous studies on sediment transport to extrapolate such plot data to the full snow-avalanche deposit area in order to obtain estimates of sediment yield, 


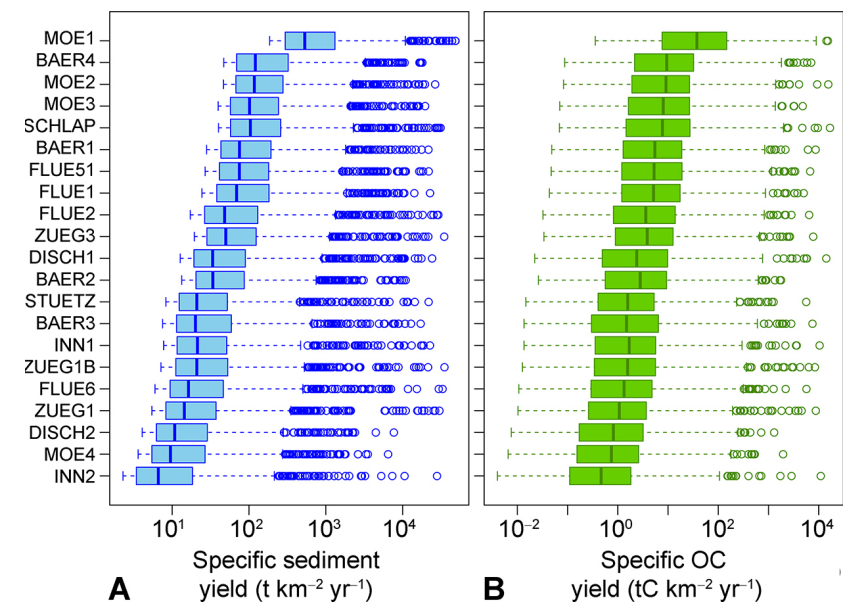

Fig. 5. Box-and-whisker plots for simulated specific sediment and organic carbon yields from $n=21$ snow-avalanche cones in the area around Davos, eastern Swiss Alps. Boxes enclose interquartile range (thick vertical lines are median values); whiskers cover 1.5 times the interquartile range; circles are outliers. Simulated data from the method outlined in the text assuming a power-law distributed deposit area with minimum $A_{\min }=100 \mathrm{~m}^{2}$. Plot highlights the spatial (= between-site) variability of specific sediment and carbon yields, which for a given median, spans two orders of magnitude.

our Monte Carlo simulations underline the minimum variability of rate estimates that may be encountered for a given study area if allowing avalanche-deposit area to vary with the sampled distribution of debris-cover thickness (Fig. 4). Even if simplistically assuming a fixed bulk density, the discrepancy between using a linear extrapolation from the plot scale and an extrapolation that uses weighted re-sampling of randomly field-measured debris-cover thickness may be substantial (Fig. 6).

The recognition that estimates of specific sediment yields from snow avalanches may be subject to substantial variability is not novel, and has been stressed before (Heckmann et al., 2002, 2005). This variability appears to be a key property of specific sediment yields tied to mass-wasting processes in general (Korup, 2012), and is not necessarily an exclusive characteristic of snow avalanches. Moreover, our rate estimates are interpolated over a single year, and should not be taken as representative of the long term. Nevertheless, we have obtained a large number of random samples from different snow-avalanche deposits that highlight the potential variance in the geomorphic and biogeochemical efficacy of snow avalanches during a single snowmelt season, if substituting space for time. While previous authors preferred estimates based on individual snow avalanches, we could not clearly distinguish between single events in our study area. Thus our estimated specific yields may encompass multiple superimposed avalanche deposits locally, although few of the dissected deposits showed any clear evidence of lay-
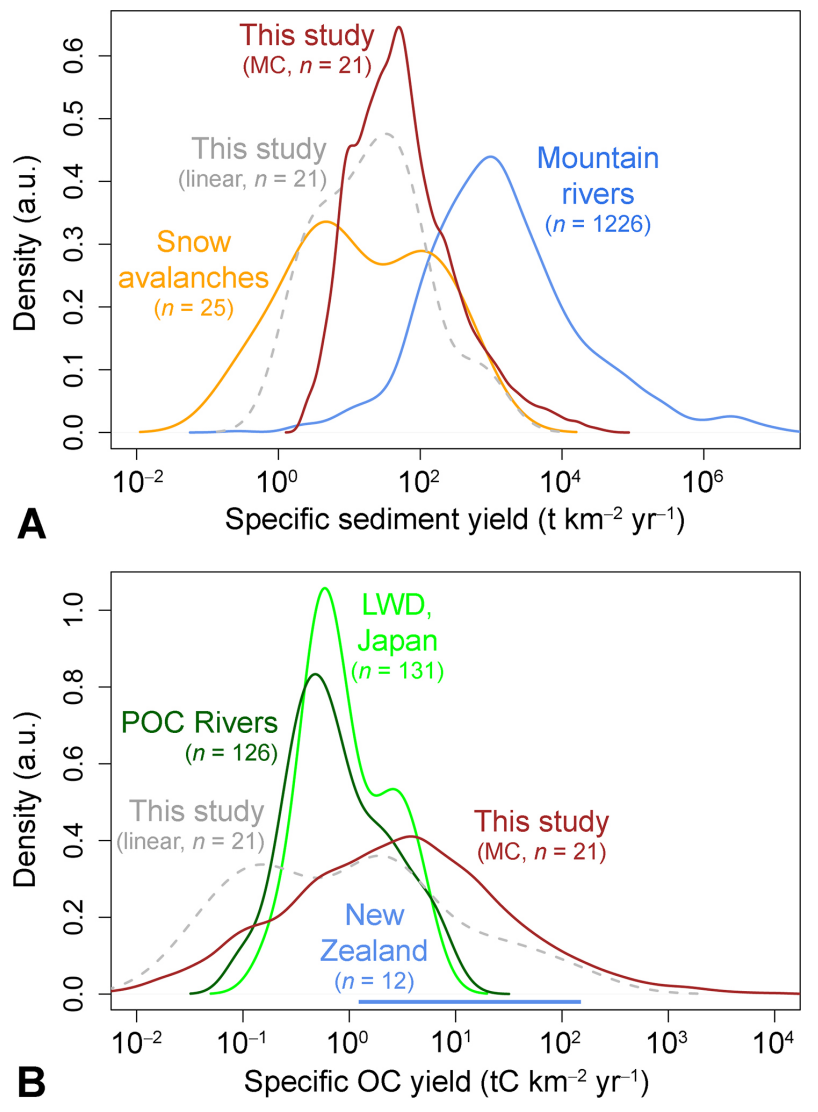

Fig. 6. Comparison of published estimates of specific sediment and particulate organic carbon (POC) yields. (A) Probability density estimates of multi-year specific sediment yields reported from mountain rivers throughout the world (Korup, 2012); attributed to snow avalanches mainly in the European Alps, and the Karakoram; and this study (MC represents a Monte Carlo-based simulation; linear represents the simple product of deposit area and mean debriscover thickness). (B) Probability density estimates of multi-year POC yields in large rivers worldwide (Beusen et al., 2005); mountain rivers in New Zealand (Carey et al., 2005; no reliable density estimate because of low sample size); large woody debris (LWD) fluxes in Japanese mountain rivers (Seo et al., 2008); and this study.

ering or buried debris. Moreover, we regard the potential bias towards clearly visible sediment and organic detritus on snow-avalanche deposits to be minimal, and our results from particle-size analysis to be accurate to first order.

Overall, our rate estimates are consistent with previous work on sediment transport by snow avalanches in the European Alps and elsewhere, as far as the high documented variability of yields, particularly during the snowmelt season (e.g. Iida et al., 2012), is concerned (Fig. 6). Most of our estimated specific sediment yields are between $10^{1}$ and $10^{2} \mathrm{t} \mathrm{km}^{-2} \mathrm{yr}^{-1}$, and thus in the upper range of reported yields for avalanches elsewhere. Translated into density-corrected catchment-wide surface lowering (soil erosion), the highest specific sediment yield 
from snow avalanches would have attained $\sim 0.5 \mathrm{~mm} \mathrm{yr}^{-1}$. Whether this involves significant amounts of bedrock erosion remains open for future research: Moore et al. (2013) estimated that snow avalanches had eroded bedrock channels at $0.01-0.05 \mathrm{~mm} \mathrm{yr}^{-1}$ from a 4-year record in a small catchment in the Matter Valley, Swiss Alps. Soil erosion by snow avalanches may be as important as comparable processes in the summer season, if not more important locally. Plot-scale experiments with sediment traps indicate that summer sheet erosion in the Alps may range between 0.05 and $10 \mathrm{t} \mathrm{km}^{-2} \mathrm{yr}^{-1}$, at least (Merz et al., 2009; Schindler Wildhaber et al., 2012). Analyses of the total erosion with ${ }^{137}$ caesium tracers and modelling approaches, however, yielded much higher values of $>10^{3} \mathrm{t} \mathrm{km}^{-2} \mathrm{yr}^{-1}$ (Konz et al., 2009). These high rates may be explained by the longer integration times of this method, thus likely also covering extreme events, including snow avalanches that may be significant erosional counterparts to summer sheet erosion. In this context, shallow landslides are additional erosion processes that deserve better quantification in order to more objectively gauge the contribution of snow avalanches.

Given that we measured sediment and organic carbon concentrations on snow bridges, most of the material is likely to be readily flushed downstream and exported from the drainage basins. Hence, we interpret our inferred specific yields as direct contributions to the fluvial export of sediment and organic carbon. Compared to current estimates of contemporary fluvial sediment yields, which in the eastern Swiss Alps may exceed $10^{3} \mathrm{t} \mathrm{km}^{-2} \mathrm{yr}^{-1}$ (Hinderer et al., 2013), our rates indicate a substantial contribution of snow avalanching at least concerning small headwater catchments. Surprisingly, our POC yield estimates clearly surpass the majority of reported POC and LWD fluxes in rivers worldwide by up to an order of magnitude (Beusen et al., 2005; Seo et al., 2008; Fig. 6b). We note that our study areas are much smaller $\left(<1 \mathrm{~km}^{2}\right)$ than in those studies, and expect that these large $\left(\gg 1000 \mathrm{~km}^{2}\right)$ river systems take in many point sources of organic carbon, as well as significant areas of little or no POC contribution that depress the overall estimates. Conversely, POC yields from smaller mountainous catchments may exceed $10^{1} \mathrm{t} \mathrm{km}^{-2} \mathrm{yr}^{-1}$ (e.g. Carey et al., 2005; Leithold et al., 2006), and thus our maximum probability density estimate (Fig. 6b). We suspect that the ratio of POC source areas to overall catchment areas may be decisive for the overall POC yields in rivers. The LWD fluxes from Japan (Seo et al., 2008) are also from mountainous catchments (with areas between 6 and $2600 \mathrm{~km}^{2}$ ), but are likely to be much higher given that biogenic carbon from sources other than LWD had not been included. While we caution against overinterpreting this finding because of differing observation periods and field methods, we note that our focus on fine (soil) sediment clearly remains an underestimate with respect to both sediment and POC delivery by snow avalanches.

\section{Conclusions}

Field sampling of $n=28$ wet snow-avalanche deposits in the eastern Swiss Alps revealed an orders-of-magnitude variability of inferred specific sediment and organic carbon yields ( 1.8 to $830 \mathrm{t} \mathrm{km}^{-2} \mathrm{yr}^{-1}$, and 0.04 to $131 \mathrm{tC} \mathrm{km}^{-2} \mathrm{yr}^{-1}$, respectively). This supports similar findings elsewhere, and underlines the importance of a well-laid-out sampling strategy when attempting to quantify sediment and carbon fluxes associated with snow avalanches. The bulk of organic content was found in the fine fraction of detritus $(<2 \mathrm{~mm})$ that we largely attribute to soil erosion in the runout path. Our Monte Carlo simulation highlights that with a minimum of free parameters such variability is inherent to the geometric scaling when computing specific yields. The hitherto used standard method of linearly extrapolating plot-sample data may be prone to substantial under- or overestimates. Despite these caveats, the range of inferred yields points to wet snow avalanches as potentially important agents of localized soil erosion and transporters of biogeochemical constituents, given that the measured detrital concentrations were located on ephemeral snow bridges prone to collapse and fluvial entrainment, and thus rapid export from these mountain drainage basins. While the inferred sediment yields are consistent with data on fluvial sediment flux in the eastern Alps, the POC yields are surprisingly high by global standards. Our results underline the relevance of erosional processes in winter and spring seasons in a mountainous area subjected to several months of snow cover each year. However, given that a number of snow bridges persisted below the insulating debris cover well into the summer months, snowavalanche deposits may also be important regulators of inchannel sediment and carbon storage on seasonal timescales. In summary, we strongly encourage further work on the geomorphic and biogeochemical efficiency of snow avalanches, as current budgets may lack a considerable fraction of sediment and POC fluxes in the snowmelt season.

Acknowledgements. This study was supported in parts by the Potsdam Research Cluster for Georisk Analysis, Environmental Change and Sustainability (PROGRESS). Statistics were computed using the R software environment (http://www.r-project.org/).

Edited by: G. H. Gudmundsson

\section{References}

Ackroyd, P: Erosion by snow avalanche and implications for geomorphic stability, Torlesse Range, New Zealand, Arctic Alpine Res., 19, 65-70, 1987.

André, M. F.: Geomorphic impact of spring avalanches in Northwest Spitsbergen $\left(79^{\circ} \mathrm{N}\right)$, Permafrost Periglac., 1, 97-110, 1990.

Bebi, P., Kulakowski, D., and Rixen, C.: Snow avalanche disturbances in forest ecosystems - state of research and implications for management, Forest Ecol. Manag., 257, 1883-1892, 2009. 
Bell, I., Gardner, J., and Descally, F.: An estimate of snow avalanche debris transport, Kaghan Valley, Himalaya, Pakistan, Arctic Alpine Res., 22, 317-321, 1990.

Beusen, A. H. W., Dekkers, A. L. M., Bouwman, A. F., Ludwig, W., and Harrison, J.: Estimation of global river transport of sediments and associated particulate C, N, and P, Global Biogeochem. Cy., 19, GB4S05, doi:10.1029/2005GB002453, 2005.

Birkeland, K. W. and Landry, C. C.: Power-laws and snow avalanches, Geophys. Res. Lett., 29, 1554, doi:10.1029/2001GL014623, 2002.

Blikra, L. H. and Selvik, S. F.: Climatic signals recorded in snow avalanche-dominated colluvium in western Norway: depositional facies successions and pollen records, Holocene, 8, 631658, 1998.

Butler, D. R.: Geomorphic process-disturbance corridors: a variation on a principle of landscape ecology, Prog. Phys. Geog., 25, 237-248, 2001.

Carey, A. E., Gardner, C. B., Goldsmith, S. T., Lyons, W. B., and Hicks, M. D.: Organic carbon yields from small, mountainous rivers, New Zealand, Geophys. Res. Lett., 32, L15404, doi:10.1029/2005GL023159, 2005.

Ceaglio, E., Meusburger, K., Freppaz, M., Zanini, E., and Alewell, C.: Estimation of soil redistribution rates due to snow cover related processes in a mountainous area (Valle d'Aosta, NW Italy), Hydrol. Earth Syst. Sci., 16, 517-528, doi:10.5194/hess-16-5172012, 2012.

Confortola, G., Maggioni, M., Freppaz, M., and Bocchiola, D.: Modelling soil removal from snow avalanches: a case study in the Italian Alps, Cold Reg. Sci. Technol., 70, 43-52, 2012.

Decaulne, A. and Saemundsson, T.: Geomorphic evidence for present-day snow-avalanche and debris-flow impact in the Icelandic Westfjords, Geomorphology, 80, 80-93, 2006.

de Scally, F., Slaymaker, O., and Owens, I.: Morphometric controls and basin response in the Cascade Mountains, Geogr. Ann. A, 83, 117-130, 2001.

Freppaz, M., Godone, D., Maggioni, M., Lunardi, S., Williams, M. W., and Zanini, E.: Soil Erosion Caused by Avalanches: a Case Study in the Aosta Valley (NW Italy), Arct. Antarct. Alp. Res., 42, 412-421, 2010.

Gardner, J. S.: Observations on erosion by wet snow avalanches, Mount Rae area, Alberta, Canada, Arctic Alp. Res., 15, 271-274, 1983.

Heckmann, T., Wichmann, V., and Becht, M.: Quantifying sediment transport by avalanches in the Bavarian Alps - first results, Z. Geomorphol., 127, 137-152, 2002.

Heckmann, T., Wichmann, V., and Becht, M.: Sediment transport by avalanches in the Bavarian Alps revisited - a perspective on modeling, Z. Geomorphol., 138, 11-25, 2005.

Hinderer, M., Kastowski, M., Kamelger, A., Bartolini, C., and Schlunegger, F.: River loads and modern denudation rates of the Alps - A review, Earth-Sci. Rev., 118, 11-44, 2013.

Huber, T. P.: The geormorphology of subalpine snow avalanche runout zones - San Juan Mountains, Colorado, Earth Surf. Proc. Land., 7, 109-116, 1982.

Humlum, O., Christiansen, H. H., and Juliussen, H.: Avalanchederived rock glaciers in Svalbard, Permafrost Periglac., 18, 7588, 2007.
Iida, T., Kajihara, A., Okubo, H., and Okajima, K.: Effect of seasonal snow cover on suspended sediment runoff in a mountainous catchment, J. Hydrol., 428-429, 116-128, 2012.

Jomelli, V.: Snow avalanche deposits in the French Alps: Geometry, sedimentology and geodynamic since the Little Ice Age, Geogr. Phys. Quatern., 53, 199-209, 1999.

Jomelli, V. and Bertran, P.: Wet snow avalanche deposits in the French Alps: Structure and sedimentology, Geogr. Ann. A, 83, 15-28, 2001.

Konz, N., Schaub, M, Prasuhn, V., Baenninger, D., and Alewell, C.: Cesium-137-based erosion-rate determination of a steep mountainous region, J. Plant Nutr. Soil Sc., 172, 615-622, 2009.

Korup, O.: Earth's portfolio of extreme sediment transport events, Earth-Sci. Rev., 112, 115-125, 2012.

Kulakowski, D., Bebi, P., and Rixen, C.: The interacting effects of land use change, climate change and suppression of natural disturbances on landscape forest structure in the Swiss Alps, Oikos, 120, 216-225, 2011.

Leithold, E. L., Blair, N. E., and Perkey, D. W.: Geomorphologic controls on the age of particulate organic carbon from small mountainous and upland rivers, Global Biogeochem. Cy., 20, GB3022, doi:10.1029/2005GB002677, 2006.

Luckman, B. H.: Geomorphic activity of snow avalanches, Geogr. Ann. A, 59, 31-48, 1977.

Luckman, B. H.: Geomorphic work of snow avalanches in the Canadian Rocky Mountains, Arctic Alpine Res., 10, 261-276, 1978.

Luckman, B., Matthews, J., Smith, D., McCarroll, D., and McCarthy, D.: Snow-Avalanche Impact Landforms: A Brief Discussion of Terminology, Arct. Alpine Res., 26, 128-129, 1994.

Merz, A., Alewell, C., Hiltbrunner, E., and Baenninger, D.: Plantcompositional effects on surface runoff and sediment yield in subalpine grassland, J. Plant Nutr. Soil Sc., 172, 777-788, 2009.

Moore, J., Egloff, J., Nagelisen, J., Hunziker, M., Aerne, U., and Christen, M.: Sediment transport and bedrock erosion by wet snow avalanches in the Guggigraben, Matter Valley, Switzerland, Arct. Antarct. Alp. Res., 45, 350-362, 2013.

Nyberg, R.: Observations of slushflows and their geomorphological effects in the Swedish Mountains area, Geogr. Ann. A, 71, 185198, 1989.

Rixen, C., Haag, S., Kulakowski, D., and Bebi, P.: Natural avalanche disturbance shapes plant diversity and species composition in subalpine forest belt, J. Veg. Sci., 18, 735-742, 2007.

Sass, O., Hoinkis, R., and Wetzel, K. F.: A six-year record of debris transport by avalanches on a wildfire slope (Arnspitze, Tyrol), Z. Geomorphol., 54, 181-193, 2010.

Schindler Wildhaber, Y., Baenninger, D., Burri, K., and Alewell, C.: Evaluation and application of a portable rainfall simulator on subalpine grassland, Catena, 91, 56-62, 2012.

Seo, J. I., Nakamura, F., Nakano, D., Ichiyanagi, H., and Chun, K. W.: Factors controlling the fluvial export of large woody debris, and its contribution to organic carbon budgets at watershed scales, Water Resour. Res., 44, W04428, doi:10.1029/2007WR006453, 2008.

Schweizer, J., Jamieson, R. B., and Schneebeli, M.: Snow avalanche formation, Rev. Geophys., 41, 2-1-2-45, 2003.

Sovilla, B., Burlando, P., and Bartelt, P.: Field experiments and numerical modeling of mass entrainment in snow avalanches, $\mathrm{J}$ Geophys. Res., 111, F03007, doi:10.1029/2005JF000391, 2006. 
Stanchi, S., Freppaz, M., Ceaglio, E., Maggioni, M., Meusburger, K., Alewell, C., and Zanini, E.: Soil erosion in an avalanche release site (Valle d'Aosta: Italy): towards a winter factor for RUSLE in the Alps, Nat. Hazards Earth Syst. Sci. Discuss., 2, 1405-1431, doi:10.5194/nhessd-2-1405-2014, 2014.
Ward, R. G. W.: Geomorphological evidence of avalanche activity in Scotland, Geogr. Ann. A, 67, 247-256, 1985. 